\title{
On an Attempt to Explore the Possible Challenges Faced during the Solid Waste Management using ISM Methodology
}

\author{
Lakshay Aggarwal \\ Recventures Education \\ Services Private Limited \\ Delhi, India
}

\author{
Veena Aggarwal \\ Recventures Education \\ Services Private Limited \\ Delhi, India
}

\author{
Remica Aggarwal \\ Recventures Education \\ Services Private Limited \\ Delhi, India
}

\author{
V. K. Aggarwal \\ Recventures Education \\ Services Private Limited \\ Delhi, India
}

\begin{abstract}
Following research work focuses on exploring the possible challenges for solid waste management practices in developing countries such as India. It compares the two methodologies of qualitative decision making i.e. ISM and Fuzzy ISM methodologies for establishing the interrelationship amongst them.
\end{abstract}

\section{Keywords}

Solid waste management ; ISM methodology ; Incineration, Solid waste, Hazardous, Non-hazardous

\section{INTRODUCTION}

India is rapidly shifting from agricultural-based nation to industrial and services-oriented country. About 31.2\% population is now living in urban areas. Over 377 million urban people are living in 7,935 towns/cities. India is a vast country divided into 29 States and 7 Union Territories (UTs). There are three mega cities-Greater Mumbai, Delhi, and Kolkata - having population of more than 10 million, 53 cities have more than 1 million population, and 415 cities having population 100,000 or more [1-2]. India has different geographic and climatic regions (tropical wet, tropical dry, subtropical humid climate, and mountain climate) and four seasons (winter, summer, rainy and autumn) and accordingly residents living in these zones have different consumption and waste generation pattern.

Rapid urbanization is one of the major factor in which our country is facing a massive waste management challenge today. India suffers from inadequate waste infrastructure and a tremendous increase in solid waste generation per capita. Segregation of waste at source and resource recovery is the key to well- established waste management practice in India. Sanitary landfills are considered to be ultimate means of disposal waste that cannot be reused or recycled. The logistic cost involves transportation of waste to landfill sites which is considered as a major limitation to this method.

In Urban areas people working in the informal sector make a living through the collection (door to door), sorting, recycling

and selling post-consumer waste. The waste pickers and itinerant waste buyers are not socially accepted, equally treated as they experience verbal, physical abuse and extortion from recycling traders. Failure of segregation of waste by the waste generators results in an inefficiency of collection of post-consumer recyclables, therefore, in the monsoon season, India experiences a variation in recovery of recyclable waste.

A solution can be considering the waste to energy process which generates energy in the form of electricity from municipal solid waste; which can be distributed or decentralized through a local body. However, such plants are not operating to their full potential in India. The majority of India's waste is organic for which installation of biomethanation and composting plants could be a solution for processing of biodegradable waste which remains underexploited in India.

The landfills in India cause $20 \%$ of the methane gas emissions, the decomposition of inorganic waste has led to contamination of the ground water. $100 \%$ success of waste collection by urban local bodies still proves to be a major challenge today only $10 \%$ of waste collected is treated, and virtually nothing is scientifically disposed of in engineered integrated sustainable waste management systems. The cities in India, especially in the major cities, have limited land for waste disposal. ULB's are unable to implement appropriate waste collection strategies due to inadequate funds, resources and infrastructure. India cannot cope with large volumes of waste generated by the increasing urban population, which does not only pose a threat to public health and the environment but is also a significant opportunity for economic gains. India generates 60 million tons of trash every year; the landfills are overflowing with no territorial space for addition land. Delhi produces 9,000 metric tons of municipal solid waste, which is dumped in four landfill sites. Three of the four sites should have been stopped by 2005 to 2009. Mumbai generates 6,500 metric tons of garbage daily out of which 4,500 metric tons is dumped at Deonar dumping ground which is proposed to expire at the end of 2016.

\subsection{Composition and characteristics of Indian municipal solid waste}

Following major categories of waste are generally found in MSW of India:

- Biodegradable Waste: Food and kitchen waste, green waste (vegetables, flowers, leaves, fruits) and paper.

- Recyclable Material: Paper, glass, bottles, cans, metals, certain plastics, etc.

- Inert Waste Matter: $\mathrm{C} \& \mathrm{D}$, dirt, debris.

- Composite waste: Waste clothing, Tetra packs, waste plastics such as toys.

- Domestic Hazardous Waste includes waste medicine, e-waste, paints, chemicals, light bulbs, fluorescent tubes, spray cans, fertilizer and pesticide containers, batteries, and shoe polish.

- MSW in India has approximate 40-60\% compostable, $30-50 \%$ inert waste and $10 \%$ to $30 \%$ recyclable. 
- Analysis carried out by NEERI reveals that in totality Indian waste consists of Nitrogen content $(0.64 \pm 0.8) \%$, Phosphorus $(0.67 \pm 0.15) \%$, Potassium $(0.68 \pm 0.15) \%$, and $\mathrm{C} / \mathrm{N}$ ration $(26 \pm 5)$ $\%$.

- In absence of any concrete steps taken to analyse the regional, researchers have to rely on the limited data available based on the study conducted by Central Pollution Control Board (CPCB), New Delhi [7-9]; National Engineering and Environmental Research Institute (NEERI), Nagpur; Central Institute of Plastics Engineering and Technology (CIPET), Chennai; and Federation of Indian Chambers of Commerce and Industry (FICCI, 2009), New Delhi [10].

\subsection{Solid waste management practices and challenges in India [5-31]}

In India , on an average only $70 \%$ waste collection is observed, while the remaining $30 \%$ is again mixed up and lost in the urban environment. Out of total waste collected, only $12.45 \%$ waste is scientifically processed and rest is disposed in open dumps [5-7].

\subsubsection{Segregation}

Sorting of waste, is mostly accomplished by unorganized sector and seldom practiced by waste producers. On a number of occasions, due to improper handling the segregated constituents got mixed up again during transportation and disposal [7-9].

\subsubsection{Collection}

Waste produced by houses and street sweepings is usually transferred into communal bins that are fabricated from metal, made from concrete or in combination of both. These community waste bins are also used by other essential commercial sectors in the vicinity of disposal bins along with household waste except where some commercial complexes or industrial units engage municipal authorities for transfer of their waste to disposal site by paying some amount [11-12].

\subsubsection{Reuse/recycle}

This entails activities like collecting those materials from the waste, which could be gainfully retrieved and utilized for making new products. Rag-pickers usually sorted out and took and sell recyclable material like plastics, glass, etc. [13].

\subsubsection{Transportation}

Modes of transportation for MSWM practiced in India are: bullock carts, hand rickshaws, compactors, trucks, tractor, trailers, and dumpers. Stationary compactors, mobile compactors/closed tempos and tarpaulin-covered vehicles are used in the transportation of MSW and about 65\%,15\% and $20 \%$ of waste is transported through these compacters respectively.

\subsubsection{Disposal}

In India, almost every city, town, or village adopted unscientific disposal of MSW. The following disposal practices are in use in hierarchy.

\subsubsection{Open dumping}

In India, MSW generated is usually directly disposed on low lying area in routine way violating the practices of sanitary landfilling. Almost no ULBs have adequate sanitary landfilling facility and MSW is dumped in the outskirts of town along the roads.

\subsubsection{Landfilling}

Landfilling would continue to be extensively accepted practice in India[8-10]. According to CPCB, 2013 report, till date, India has 59 constructed landfill sites and 376 are under planning and implementation stage. Apart from this, 1305 sites have been identified for future use.

\subsubsection{Landfill gas-to-energy plants}

From landfills mainly methane $\left(\mathrm{CH}_{4}\right)$ and carbon dioxide $\left(\mathrm{CO}_{2}\right)$ gases are produced. These gases have significant greenhouse effect. $\mathrm{CH}_{4}$ emission from landfill is about $13 \%$ of global $\mathrm{CH}_{4}$ emission and is about 818 million metric tons per annum in terms of $\mathrm{CO}_{2}$ equivalent . The utilization of landfill gas, particularly $\mathrm{CH}_{4}$ for energy production is important as it finally converts into primary constituents (i.e. $\mathrm{CO}_{2}$ and $\mathrm{H}_{2} \mathrm{O}$ ).

\subsubsection{Biological treatment of organic waste}

The waste generated in India has more organic contentabout $50 \%$ - as compared to $30 \%$ generated by developed countries. Following composting methods are commonly adopted in India:

\subsubsection{Aerobic composting}

Composting is defined as the phenomenon under which biological conversion of organic matter existing in MSW takes place in the presence of air under humid and warm environment. The end product of composting, having high nutrient value, is humus (compost).

1.2.5.6. Vermi-composting. Vermicomposting is carried out by introducing earthworms on semi-decomposed organic waste.

1.2.5.7. Anaerobic digestion. Anaerobic decomposition of waste is also known as bio-methanation process. In this process, stabilization occurs and biogas is liberated by the conversion of organic matter, which in turn can be used as energy. The biogas has 55-60\% methane and it can be used as fuel for power generation.

\subsubsection{Thermal treatment}

Thermal treatment of solid wastes can be accomplished by Incineration, Pyrolysis and Plasma arc gasification. Incineration of Indian MSW is not suitable as the MSW has high organic constituents, moisture content, or inert content in the waste in the range of $30 \%$ to $60 \%$ each and calorific value in the range of $800-1,100 \mathrm{kcal} / \mathrm{kg}$ in MSW [14-16]. Two different designs of gasifiers can be seen in India. The first one (Nerifier gasification unit) has been installed at Nohar, Hanumangarh, Rajasthan by Narvreet Energy Research and Information (NERI) for burning of agro-wastes, sawmill dust, and forest wastes, while the second one is the Tata Energy Research Institute (TERI) gasifier installed at Gaul Pahari campus, New Delhi [8-10].

Present research is organized as follows . Section 2 describes the various challenges faced by Indian government for the treatment of solid waste management. Section 3 presents the ISM and fuzzy ISM approach. Section 4 the conclusions and future directions.

\section{CHALLENGES FACED BY INDIAN GOVERNMENT FOR THE TREATMENT OF SOLID WASTE MANAGEMENT}

\subsection{Lack of awareness to enhance} segregation (AES): Ecological awareness and citizen participation to segregate waste at source, door-to-door 
collection, and disposal in appropriate collecting bin is imperative. Also, due to lack of coordination among the residents and lack of planned cities in India, the residents throw garbage improperly.

\subsection{Lack of Characterization of municipal} solid waste (CMSW): India is a vast country divided into different climatic zone, different food habits, and different living standard thereby producing waste of different types. Till date, no comprehensive studies have been conducted to cover almost all cities and towns of India to characterize the waste generated and disposed on landfill and hence it is a challenge.

\subsection{Urbanization and lack of appropriate} level funding (ULLF): With the population growth, challenge to provide adequate infrastructure in urban area and new landfill site selection is important. Most of the landfill sites are running beyond their capacity in metropolitan cities. Inadequate financial support to cater to waste management problem aggravates it

\subsection{Implementation of rules at ground level} (IRGL): There is a need to create dedicated group of officers and skilled staff for ULBs with specialization in MSWM. Adequate training and hands-on experiments would enable them to identify bottlenecks at implementation level and take appropriate action.

\subsection{Financial auditing and work study (FAWS)}

\subsection{Resistance for notification of new}

landfill site (RNLS): There is resistance of local citizen for notification of landfill site in their locality and therefore selection of new site is difficult and all the existing landfill sites are running beyond their capacity.

\subsection{Lack of coordination among Centre and}

State (LCCS): There is less dialogue between Central and State government. Delay in submission of information from State to Central delays appropriate level implementation at ground level. Such lack of coordination for specific action plan and poor strategy at implementation level by ULBs are main hindrance.

\subsection{Appropriate technological solution,} Outsourcing and PPP (ATSO): Environmentally benign practices are the need of the hour to cope with the almost exponential growth of MSW. For this, appropriate technological solutions through PPP are required. However, lack of competency and insufficient financial support are major threats to ULBs for development of MSW infrastructure. There is need for PPP to implement management and handling with the latest technology/ knowhow with the subject experts firms and companies.

\subsection{Failure of waste-to-energy projects}

(FWEP): India is still struggling to make waste-to-energy project a success story. There is a need to import economically feasible and proven technologies. Apart from this, suitably characterized and segregated waste needs to be provided to waste-to-energy plants as per its requirement.

\subsection{Involvement of organized sector (IOS):}

For improving MSW collection efficiency and source segregations, rag-pickers can be engaged through organized sector. However, due to lack of recycling industries and acceptance of society this vast potential has been ignored.

\section{INTERPRETIVE STRUCTURAL MODELLING METHODOLOGY}

Interpretive structural modelling methodology or ISM [31] is a known technique to map the relationships amongst the relevant elements as per decision maker's problems in a hierarchical manner. Starting with the identification of elements, it proceeds with establishing the contextual relationships between elements (by examining them in pairs ) and move on towards developing the structural selfinteraction (SSIM) matrix using VAXO and then initial reachability matrix and final reachability matrix and rearranging the elements in topological order using the level partition matrices. A Mic-Mac analysis is performed afterwards which categorize the variables as per the driving and dependence power in to autonomous, dependent, driver and linkage category. Finally, a diagraph can be obtained.

\section{CASE EXAMPLE}

The 10 challenges viz. Awareness to enhance segregation (AES) ; Characterization of municipal solid waste (CMSW) ; Urbanization and lack of appropriate level funding (ULLF) ; Implementation of rules at ground level (IRGL) ; Financial auditing and work study (FAWS) ; Resistance for notification of new landfill site (RNLS); Lack of coordination among Centre and State (LCCS); Appropriate technological solution, Outsourcing and PPP (ATSO) ; Failure of waste-to-energy projects (FWEP) ; Involvement of organized sector (IOS) described in section 2 above are being further studied for the possible inter-relationships amongst them.

Fig 1: SSIM matrix for pair wise relationship amongst barriers

\begin{tabular}{|c|c|c|c|c|c|c|c|c|c|c|c|}
\hline $\begin{array}{c}\text { S. } \\
\text { No. }\end{array}$ & Barriers & 1 & 2 & 3 & 4 & 5 & 6 & 7 & 8 & 9 & 10 \\
\hline & & LKA & AHM & LTE & PPRN & IETIE & PSR & ESR & PWSP & PHWW & LoA \\
\hline 1 & LKA & 1 & 0 & 0 & 1 & 1 & 1 & 1 & 1 & 1 & 1 \\
\hline 2 & AHM & 1 & 1 & 1 & 1 & 1 & 1 & 1 & 1 & 1 & 1 \\
\hline 3 & LTE & 1 & 0 & 1 & 1 & 1 & 1 & 1 & 1 & 1 & 1 \\
\hline 4 & PPRN & 0 & 0 & 0 & 1 & 1 & 1 & 1 & 1 & 1 & 1 \\
\hline 5 & IETIE & 0 & 0 & 0 & 1 & 1 & 1 & 1 & 1 & 1 & 1 \\
\hline 6 & PSR & 0 & 0 & 0 & 0 & 0 & 1 & 1 & 0 & 0 & 0 \\
\hline
\end{tabular}




\begin{tabular}{|c|c|c|c|c|c|c|c|c|c|c|c|}
\hline 7 & ESR & 0 & 0 & 0 & 0 & 0 & 1 & 1 & 0 & 0 & 0 \\
\hline 8 & PWSP & 0 & 0 & 0 & 0 & 0 & 1 & 1 & 1 & 1 & 0 \\
\hline 9 & PHWW & 0 & 0 & 0 & 0 & 0 & 1 & 1 & 1 & 1 & 0 \\
\hline 10 & LoA & 0 & 0 & 0 & 0 & 0 & 1 & 1 & 1 & 1 & 1 \\
\hline
\end{tabular}

Fig 2: Initial reachability matrix

\begin{tabular}{|c|c|c|c|c|c|c|c|c|c|c|c|c|}
\hline $\begin{array}{c}\text { S. } \\
\text { No. }\end{array}$ & Barriers & 1 & 2 & 3 & 4 & 5 & 6 & 7 & 8 & 9 & 10 & D.P \\
\hline & & LKA & AHM & LTE & PPRN & IETIE & PSR & ESR & PWSP & PHWW & LoA & \\
\hline 1 & LKA & 1 & 0 & 0 & 1 & 1 & 1 & 1 & 1 & 1 & 1 & 8 \\
\hline 2 & AHM & 1 & 1 & 1 & 1 & 1 & 1 & 1 & 1 & 1 & 1 & 10 \\
\hline 3 & LTE & 1 & 0 & 1 & 1 & 1 & 1 & 1 & 1 & 1 & 1 & 9 \\
\hline 4 & PPRN & 0 & 0 & 0 & 1 & 1 & 1 & 1 & 1 & 1 & 1 & 7 \\
\hline 5 & IETIE & 0 & 0 & 0 & 1 & 1 & 1 & 1 & 1 & 1 & 1 & 7 \\
\hline 6 & PSR & 0 & 0 & 0 & 0 & 0 & 1 & 1 & 0 & 0 & 0 & 1 \\
\hline 7 & ESR & 0 & 0 & 0 & 0 & 0 & 1 & 1 & 0 & 0 & 0 & 1 \\
\hline 8 & PWSP & 0 & 0 & 0 & 0 & 0 & 1 & 1 & 1 & 1 & 0 & 4 \\
\hline 9 & PHWW & 0 & 0 & 0 & 0 & 0 & 1 & 1 & 1 & 1 & 0 & 4 \\
\hline 10 & LoA & 0 & 0 & 0 & 0 & 0 & 1 & 1 & 1 & 1 & 1 & 5 \\
\hline De.P & & 3 & 1 & 2 & 5 & 5 & 10 & 10 & 8 & 8 & 6 & \\
\hline
\end{tabular}

Fig 3 : Final reachability matrix

\begin{tabular}{|c|c|c|c|c|c|c|c|c|c|c|c|c|}
\hline $\begin{array}{c}\text { S. } \\
\text { No. }\end{array}$ & Barriers & 1 & 2 & 3 & 4 & 5 & 6 & 7 & 8 & 9 & 10 & D.P \\
\hline & & LKA & AHM & LTE & PPRN & IETIE & PSR & ESR & PWSP & PHWW & LoA & \\
\hline 1 & LKA & 1 & 0 & 0 & 1 & 1 & 1 & 1 & 1 & 1 & 1 & 8 \\
\hline 2 & AHM & 1 & 1 & 1 & 1 & 1 & 1 & 1 & 1 & 1 & 1 & 10 \\
\hline 3 & LTE & 1 & 0 & 1 & 1 & 1 & 1 & 1 & 1 & 1 & 1 & 9 \\
\hline 4 & PPRN & 0 & 0 & 0 & 1 & 1 & 1 & 1 & 1 & 1 & 1 & 7 \\
\hline 5 & IETIE & 0 & 0 & 0 & 1 & 1 & 1 & 1 & 1 & 1 & 1 & 7 \\
\hline 6 & PSR & 0 & 0 & 0 & 0 & 0 & 1 & 1 & 0 & 0 & 0 & 1 \\
\hline 7 & ESR & 0 & 0 & 0 & 0 & 0 & 1 & 1 & 0 & 0 & 0 & 1 \\
\hline 8 & PWSP & 0 & 0 & 0 & 0 & 0 & 1 & 1 & 1 & 1 & 0 & 4 \\
\hline 9 & PHWW & 0 & 0 & 0 & 0 & 0 & 1 & 1 & 1 & 1 & 0 & 4 \\
\hline 10 & LoA & 0 & 0 & 0 & 0 & 0 & 1 & 1 & 1 & 1 & 1 & 5 \\
\hline De.P & & 3 & 1 & 2 & 5 & 5 & 10 & 10 & 8 & 8 & 6 & \\
\hline
\end{tabular}

D.P : Driving power ; De.P : dependence power

\subsection{Level Partition}

From the final reachability matrix, reachability and final antecedent set for each factor are found. The elements for which the reachability and intersection sets are same are the top-level element in the ISM hierarchy. After the identification of top level element, it is separated out from the other elements and the process continues for next level of elements. Reachability set, antecedent set, intersection set along with different level for elements have been shown below in table 4.3.1.

Table 4.3.1: Iteration I

\begin{tabular}{|c|c|c|c|c|}
\hline $\begin{array}{c}\text { S.No } \\
\text { • }\end{array}$ & $\begin{array}{c}\text { Reachabili } \\
\text { ty set }\end{array}$ & $\begin{array}{c}\text { Antecedent } \\
\text { set }\end{array}$ & $\begin{array}{c}\text { Intersect } \\
\text { ion set }\end{array}$ & Level \\
\hline $\mathbf{1 .}$ & $\mathbf{6 , 7}$ & $\begin{array}{c}\mathbf{1 , 2 , 3 , 4 , 5 , 6 , 7 , 8} \\
\mathbf{9 , 1 0}\end{array}$ & $\mathbf{6 , 7}$ & I \\
\hline 2. & $6,7,8,9$ & $1,2,3,4,5,8,9,1$ & $\mathbf{8 , 9}$ & II \\
\hline
\end{tabular}




\begin{tabular}{|c|c|c|c|c|}
\hline & & 0 & & \\
\hline 3. & $6,7,8,9,10$ & $1,2,3,4,5,10$ & 10 & III \\
\hline 4. & $\begin{array}{c}4,5,6,7,8,9 \\
10\end{array}$ & $1,2,3,4,5$ & 4,5 & IV \\
\hline 5. & $\begin{array}{c}1,4,5,6,7,8 \\
9,10\end{array}$ & $1,2,3$ & 1 & V \\
\hline 6. & $\begin{array}{c}1,3,4,5,6,7 \\
8,9,10\end{array}$ & 2,3 & 3 & VI \\
\hline 7. & $\begin{array}{c}1,2,3,4,5,6 \\
7,8,9,10\end{array}$ & 2 & 2 & VII \\
\hline
\end{tabular}

\section{LITERARY OBSERVATIONS AND RECOMMENDATIONS}

Corporate Social responsibility and Solid waste management

Ref : https://thecsrjournal.in/cleaning-india-managingwaste/

- Social responsibility is "responsibility of an organization for the impacts of its decisions and activities on society and the environment through transparent and ethical behaviour that; contributes to sustainable development, including health and the welfare of society; takes into account the expectations of stakeholders; in compliance with applicable law and consistent with international norms of behaviour; as in integrated throughout the organization and practices in its relationship." (ISO 26000: Guidance on Social Responsibility, 2010).

- $\quad$ Solid waste management is a global issue. Landfill sites have become a major source of contamination, affecting water and the air in Indian cities due to increased suspension of particulates, emanating from these sites. Instigating control and management of landfills, and biodegradable waste is critical for maintaining sustainability. India would do well to have an aim at phasing out landfilling by 2025 for recyclable waste.

- Taking responsibility for one's own domestic waste disposal will enable the success of Swachh Bharat Abhiyan. There is a lack of civic sense and appreciation for public spaces. The waste outside as personified by soil, food and water has differential functional implications for an Indian. Corporate India should address pertinent issues like waste reduction, community participation in segregation of waste at source, recycling and converting waste into energy as part of their CSR programme.

- Waste management has a great potential for Companies to get good return as well as contribute to the society by promoting the recycling industry along with eco-industrial production. Following are sustainable projects implemented by Indian Companies.

\begin{tabular}{|c|c|c|c|}
\hline & Company & $\begin{array}{c}\text { Head- } \\
\text { quarters }\end{array}$ & Highlights \\
\hline & \multicolumn{3}{|c|}{ Category : Bio-methanation } \\
\hline 1. & $\begin{array}{l}\text { M/S Asia } \\
\text { Bio-energy } \\
\text { Pvt. Ltd. }\end{array}$ & Chennai & $\begin{array}{c}\text { Follows bio-gas induced } \\
\text { mixing arrangement } \\
\text { (BIMA) technology for a } \\
\text { 5.1 MW MSW to energy } \\
\text { project }\end{array}$ \\
\hline 2. & $\begin{array}{l}\text { Cicon } \\
\text { Environment } \\
\text { technologies }\end{array}$ & Bhopal & $\begin{array}{l}\text { Upflow anaerobic sludge } \\
\text { blanket (UASB) and } \\
\text { activated sludge process } \\
\text { are followed in } \\
\text { installation. }\end{array}$ \\
\hline & \multicolumn{3}{|c|}{ Category : Combustion incineration } \\
\hline 1. & $\begin{array}{c}\text { SELCO } \\
\text { International } \\
\text { Limited }\end{array}$ & Hyderabad & $\begin{array}{c}\text { Undertaking } \\
\text { comprehensive bio- } \\
\text { methanation projects } \\
\text { coupled to secure } \\
\text { composting and landfills }\end{array}$ \\
\hline 2. & $\begin{array}{c}\text { Sound craft } \\
\text { industries }\end{array}$ & Mumbai & $\begin{array}{c}\text { Installing } 12.8 \mathrm{MW} \text { plant } \\
\text { at Mumbai with } \\
\text { technology from } \\
\text { Ericksons USA }\end{array}$ \\
\hline
\end{tabular}

\section{ACKNOWLEDGEMENTS}

Our thanks to the anonymous reviewers whose comments have helped us in improving the manuscript . Co-author Remica Aggarwal is also thankful to Prof. S.P Singh from DMS ,IIT Delhi for disseminating the knowledge on ISM methodology.

\section{REFERENCES}

[1] Census 2011a. Provisional population totals, India.http://censusindia.gov.in/2011-provresults/datafiles/india/povpoputotalpresentation2011.pdf

[2] Census. 2011b. Registrar general of India. Retrieved from http://censusindia.gov.in/

[3] Rachel, G., Damodaran, N., Panesar, B., Leatherwood, C., \& Asnani, P. U. (2007, September 5-7). Methane to markets and landfill gas energy in India. In Proceeding of the International Conference on Sustainable Solid Waste Management, pp. 519-525, Chennai.

[4] CPCB. 2013. Status report on municipal solid waste management.http://www.cpcb.nic. in/divisionsofheadoffice/pcp/MSW_Report.pdfhttp://prat ham.org/images/paper_on_ragpickers.pdf

[5] CPCB 2000b. Status of municipal solid waste generation, collection, treatment and disposal in class I cities .rhttp://www.bvucoepune.edu.in/pdf's/Research\%20and \%20Publication/Research\%20Publication_2007-08/ International\%20Conference_200708/Municipal\%20soli d\%20Prof\%20MR\%20Gidde.pdf

[6] CPCB. 2014. List of registered E-waste dismantler/recycler in the country. http://www.cpcb.nic.in/e-waste_Registration_List.pdf

[7] Sharholy, M., Ahmad, K., Mahmood, G., \& Trivedi, R. C. 2005. Analysis of municipal solid waste management systems in Delhi-A review. In Proceedings for the 
second International Congress of Chemistry and Environment, Indore.

[8] Sharholy, M., Ahmad, K., Vaishya, R. C. \& Gupta, R. D. 2007. Municipal solid waste characteristics and management in Allahabad, India. Waste Management, 27, 490-496.

[9] Sharholy, M., Ahmad, K., Mahmood, G., \& Trivedi, R. C. 2008. Municipal solid waste management in Indian cities-A review. Waste Management, 28, 459-467.

[10] Federation of Indian Chambers of Commerce and Industry. 2009. Survey on the Current Status of Municipal Solid Waste Management in Indian Cities and the Potential of Landfill Gas to Energy Projects in India. https://www.

globalmethane.org/Data/292_2_ficci_survey_09.pdf

[11] Kumar, S., Bhattacharyya, J. K., Vaidya, A. N., Chakrabarti, T., Devotta, S., \& Akolkar, A. B. 2009. Assessment of the status of municipal solid waste management in metro cities, state capitals, class I cities, and class II towns in India: An insight. Waste Management, 29, 883-895.

[12] Kumar, S., \& Gaikwad, S. A. 2004. Municipal solid waste management in Indian urban centres: An approach for betterment. In K. R. Gupta (Ed.), Urban development debates in the new millennium (pp. 100-111). New Delhi: I Atlantic \& Distributors.

[13] Pattnaik, S., \& Reddy, M. V. 2010. Assessment of municipal solid waste management in Puducherry (Pondicherry), India. Resources, Conservation and Recycling, 54, 512-520. http://dx.doi.org/10.1016/j.resconrec.2009.10.008

[14] Joardar, S. D. 2000. Urban residential solid waste management in India: Issues related to institutional arrangements. Public Works Management and Policy, 4, 319-330.

[15] http://dx.doi.org/10.1177/1087724X0044006.

[16] Joseph, K. 2002. Perspectives of solid waste management in India. In International Symposium on the Technology and Management of the treatment and Reuse of the Municipal Solid Waste. Shanghai.

[17] Kansal, A. 2002. Solid waste management strategies for India. Indian Journal of Environmental Protection, 22, 444-448.

[18] Kansal, A., Prasad, R. K., \& Gupta, S. 1998. Delhi municipal solid waste and environment-An appraisal. Indian Journal of Environmental Protection, 18, 123128.

[19] Joshi, R. \& Ahmed, S. 2016. Status and challenges of municipal solid waste management in India: A review, Cogent Environmental Science, 2: 1139434.

[20] Ahmed, S. A., \& Ali, M. 2004. Partnerships for solid waste management in developing countries: Linking theories to realities. Habitat International, 28, 467-479.

[21] Sudhir, V., Muraleedharan, V. R., \& Srinivasan, G. 1996. Integrated solid waste management in Urban India: A critical operational research framework. Socio-Economic Planning Sciences, 30, 163-181Sanitation.kerala.gov.in . http://dx.doi.org/10.1016/0038-0121(96)00012-2

[22] Ahsan, N. 1999. Solid waste management plan for Indian megacities. Indian Journal of Environmental Protection, 19, 90-95. http://dx.doi.org/10.1016/S09213449(03)00037-5.

[23] Annepu, R. K. 2012. Sustainable solid waste management in India, Waste-to-Energy Research and Technology Council (WTERT). City of New York: Columbia University. http://www.seas.columbia.edu/earth/wtert/sofos/Sustaina ble $\% 20$ Solid $\% 20$ Waste\%20Management $\% 20$ in\%20India _Final.pdf

[24] Kaushal, R. K., Varghese, G. K., \& Chabukdhara, M. 2012. Municipal solid waste management in Indiacurrent state and future challenges: A review. International Journal of Engineering Science and Technology, 4, 1473-1489.

[25] Misra, V., \& Pandey, S. D. 2005. Hazardous waste, impact on health and environment for development of better waste management strategies in future in India. Environment International, 31, 417-431. http://dx.doi.org/10.1016/j.envint.2004.08.005

[26] Mor, S., Ravindra, K., Dahiya, R. P., \& Chandra, A. 2006. Leachate characterization and assessment of groundwater pollution near municipal solid waste landfill site. Environmental Monitoring and Assessment, 118, 435-456.

[27] Pappu, A., Saxena, M., \& Asolekar, S. R. 2007. Solid wastes generation in India and their recycling potential in building materials. Building and Environment, 42, 23112320. http://dx.doi.org/10.1016/j.buildenv.2006.04.015

[28] Shekdar, A. V. 1999. Municipal solid waste management - The Indian perspective. Journal of Indian Association for Environmental Management, 26, 100108

[29] Shekdar, A. V. 2009. Sustainable solid waste management: An integrated approach for Asian countries. Waste Management, 29, 1438-1448. http://dx.doi.org/10.1016/j.wasman.2008.08.025

[30] Rajesh, P. 2019, Solid waste management- sustainability towards a better future, role of CSR - a review, Social Responsibility Journal, 15(1).

[31] Warfield, J. N. 1974. Developing interconnection matrices in structural modeling. IEEE Transactions on System, Man, and Cybernetics, SMC-4 (1), 81-87. 